\title{
Applications and limitations of uranyl ion as a photophysical probe
}

\author{
Hugh D. Burrows*, Maria da Graça Miguel \\ Departamento de Química, Universidade de Coimbra, 3049 Coimbra, Portugal
}

\begin{abstract}
Uranyl ion has a long-lived luminescent excited state, which can be used as a probe for the aggregation behaviour in a variety of surfactant and polymeric systems. The general spectroscopy and photophysics of this species are discussed, and the applications to specific micellar, microemulsion, vesicular and liquid crystalline systems presented. It is shown that both dynamic and structural information can be obtained from spectral and kinetic data. Examples of applications of uranyl probe studies to technologically important mesoscopic and mesoporous systems involving metal oxides, or their salts, and to humic acids and soils will also be reviewed. Emphasis will be given to both the advantages and restrictions on the use of this useful photophysical probe. (c) 2001 Elsevier Science B.V. All rights reserved.
\end{abstract}

Keywords: Uranyl ion; Photophysical probes; Microheterogeneous systems; Surfactant aggregates

\section{Contents}

1. Introduction . . . . . . . . . . . . . . . . . . . . . . . . 486

2. Spectroscopy, photophysics and excited state reactivity of uranyl ion . . . . . . . 487

3. Studies on aqueous micellar solutions $\ldots \ldots \ldots \ldots \ldots$. . . . . . . . . . . . 488

4. Water-in-oil (w/o) microemulsions and lyotropic liquid crystals . . . . . . . . . . . 489

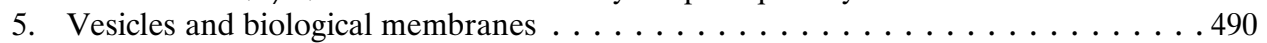

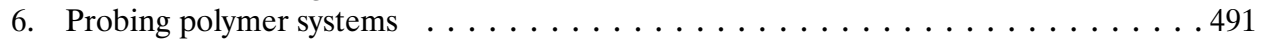

\footnotetext{
Dedicated to Professor M. Almgren on the occasion of his 60th Birthday.

*Corresponding author. Tel.: +351-239-852080; fax: +351-239-827703.

E-mail address: burrows@ci.uc.pt (H.D. Burrows).
} 
7. Metal oxides and other colloidal particles . . . . . . . . . . . . . . . . . . 491

8. Conclusions and a caveat . . . . . . . . . . . . . . . . . . . . 492

Acknowledgements . . . . . . . . . . . . . . . . . . . . . 493

References ..................................493

\section{Introduction}

Since the work of Förster and Selinger [1] on energy transfer in micelles, and subsequent studies on the fluorescence behaviour of aromatic molecules in these surfactant solutions [2-9], fluorescent probes have proved an attractive way of studying aggregation in a variety of microheterogeneous systems, and have provided information on both polarity and dynamics. These studies have been extensively reviewed [10-17]. Particularly valuable information on aggregate size has been obtained by both static and time resolved fluorescence quenching (TRFQ). $[5,8,12,16,18,19]$. This has been extended from the three-dimensional case to various reduced spatial dimensions, which may be found in aggregates such as those present in lamellar, hexagonal or bicontinuous phases [20-23]. However, by their nature, fluorescent aromatic molecules are limited to providing information resulting on diffusional processes occurring within their excited singlet state lifetimes (approx. $<500$-ns time scales), and there is increasing interest in the development of longer lived luminescent probes. Much early interest focussed on organic triplet states, studied by triplet-triplet absorption spectra, phosphorescence and energy transfer [24-27]. However, although phosphorescent probes are still used for studying slow process in polymers [28], their applications to other systems are limited by efficient quenching of triplets by molecular oxygen. The excited state properties of polypyridyl complexes of ruthenium(II) $[8,29,30]$ and chromium(III) [30] have also been used in TRFQ and other probe studies, particularly with micellar systems. However, the excited states of these complexes are also sensitive to oxygen. Several trivalent lanthanide ions possess long-lived excited states, which make them potentially valuable probes of structure in microheterogeneous systems. They possess well-defined luminescence resulting from $f-f$ transitions [31] and information on hydration can be obtained by studying deuterium isotope effects on lifetimes [32]. In addition, in the case of Eu(III), the ${ }^{7} \mathrm{~F}_{0} \rightarrow{ }^{5} \mathrm{D}_{0}$ luminescent transition is sensitive to the coordination environment [33]. However, the lanthanide $f \rightarrow f$ transitions are generally forbidden by both spin and Laporte selection rules, and are very weak [34]. Where lanthanide ions have been used as photophysical probes in microheterogeneous systems [35,36] they are generally complexed to fairly bulky ligands, which can transfer energy intramolecularly upon photoexcitation, or are energy acceptors from organic triplet energy donors $[26,37,38]$.

There is, thus, still the need for more long-lived photophysical probes for these systems. In this article we will show that excited uranyl ion $\left(\mathrm{UO}_{2}^{2+}\right)$ presents many attractive properties in this area. We will start with a brief discussion of its spectra 
and photophysics. We will then consider its applications as probe in a variety of systems. Finally, we will highlight certain pitfalls and limitations on its use.

\section{Spectroscopy, photophysics and excited state reactivity of uranyl ion}

The uranyl ion possesses structured absorption and emission bands in the visible, and also has a convenient excited state absorption band [39,40], which has been proposed as a convenient standard for transient molar absorption coefficient measurements [41]. In acidic aqueous solutions in the absence of complexing ligands, uranyl ion is present as $\mathrm{UO}_{2}\left(\mathrm{H}_{2} \mathrm{O}\right)_{5}^{2+}$ [42-45]. The absorption, emission and excited state absorption spectra of this species are shown in Fig. 1. The luminescence of this species is not quenched by molecular oxygen [46], and although its lowest energy absorption band only has a fairly low molar absorption coefficient ( $a \approx 10 \mathrm{M}^{-1} \mathrm{~cm}^{-1}$ [47]), the complex has fairly strong absorption bands in the near ultraviolet which can be readily excited with conventional light sources, including the lasers most commonly used in transient absorption and emission spectral measurements. In addition, the vibronic structure on the spectra, which is associated with the $\mathrm{O}=\mathrm{U}=\mathrm{O}$ symmetric stretching vibration $[48,49]$, is strongly dependent on the coordination symmetry around the uranyl ion [50]. Changes in intensity and bandwidth of both absorption and emission spectra can yield valuable information about the local environment. Although the normal aquo-complex has five water molecules coordinated to the linear $\mathrm{O}=\mathrm{U}=\mathrm{O}^{2+}$ group, other complexes having 4,5 or 6 ligands coordinated in the plane normal to the uranyl group are well established [51].

Uranyl ion shows a strong tendency to hydrolyse on increasing $\mathrm{pH}$ in both the ground and excited state [43,44,46,49,52,53]. Both spectra and luminescence lifetimes can be used as valuable probes of local $\mathrm{pH}$.

Uranyl ion luminescent lifetimes are strongly dependent on the coordination environment. A lifetime of $\approx 5 \mathrm{~ms}$ has been reported for $\mathrm{UO}_{2} \mathrm{~F}_{4}^{2-}$ in a single crystal matrix [54]. In contrast, in aqueous solutions the lifetime is approximately $1 \mu \mathrm{s}[39,49,53]$, whilst even shorter lifetimes may be observed in organic solvents. In aqueous solutions, the decay shows a pronounced deuterium isotope effect [39,55], which can also provide valuable information. Above $\mathrm{pH} 2-3$, the luminescence decay is multiexponential, due to emission from the different hydrolysed species $[43,44,46,47,53,56]$.

Excited uranyl ion is a strong oxidant $\left(E^{\circ}=2.6 \mathrm{~V}\right.$ [57-59] $)$ and undergoes bimolecular reactions with a number of species. With aliphatic alcohols the dominant reaction is hydrogen atom abstraction [60-62], while with metal ions $[57,63,64]$ and inorganic anions [65] quenching involves electron transfer. The kinetics of these quenching reactions, which can be valuable in probe studies on microheterogeneous systems, have recently been reviewed by Baird and Kemp [66]. General reviews of uranyl spectroscopy and photophysics are given by Balzani et al. [58], Jorgensen and Reisfield [59], Burrows and colleagues [60,61], Gusten [67] and Denning [68]. 


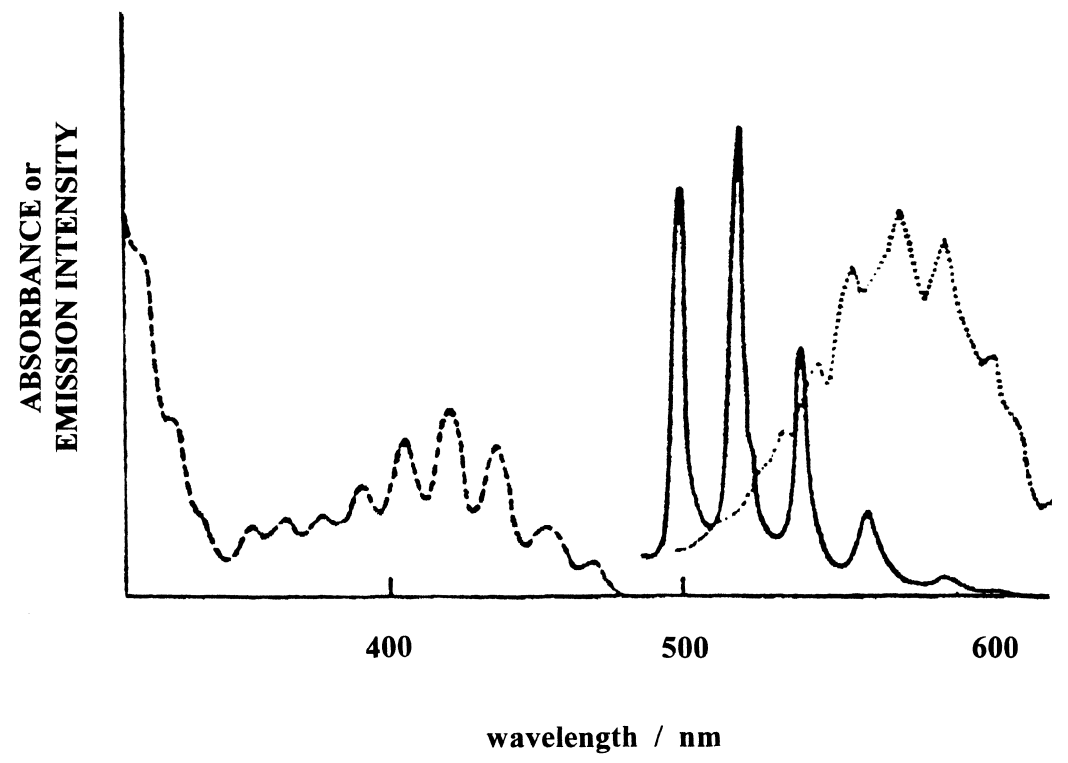

Fig. 1. Absorption (---), emission (-) and excited state absorption ( $\cdots)$ spectra of $\mathrm{UO}_{2}\left(\mathrm{H}_{2} \mathrm{O}\right)_{5}^{2+}$ in aqueous solutions.

\section{Studies on aqueous micellar solutions}

Aqueous micellar solutions containing uranyl ions have a number of important practical applications. For example, in separation science micellar-enhanced ultrafiltration has been shown to be a valuable way of quantitatively removing uranyl ions from aqueous solutions [69]. Furthermore, photolysis of uranyl salts in micelles in a magnetic field has been shown to have potential for uranium isotopic enrichment [70,71].

We will now consider some of the ways in which uranyl photophysics has contributed to our knowledge of structure in these systems. Addition of the surfactants sodium dodecylsulfate (SDS), cetyltrimethylammonium bromide (CTAB) or Triton X-100 to aqueous solutions of uranyl ion leads to quenching of the uranyl fluorescence without any significant change in the emission spectrum [72]. Stern-Volmer plots showed different behaviour below and above the critical micelle concentration (c.m.c.), giving two linear regions with different slopes. Values of the c.m.c. determined from the point of discontinuity for CTAB and Triton X-100 are in good agreement with literature values [72]. With SDS, the discontinuity occurred at lower concentrations than the c.m.c. of pure surfactant, and was dependent on $\mathrm{UO}_{2}^{2+}$ concentration [72]. This may be due to some complexing of the surfactant with the uranyl ion. Pulse radiolysis studies on the reaction of hydrated electrons with uranyl ion in the presence of SDS have also indicated cation-aggregate interactions below the normal c.m.c. [73]. However, 
although this was interpreted in terms of formation of pre-micellar aggregates [73], it is probably better considered as a lower c.m.c. for the uranyl/sodium dodecylsulfate aggregates. Laser-induced time-resolved spectrofluorimetry has been used to study the interaction of uranyl ions with sodium alkylsulfonate and alkylsulfate micelles [74-77]. It is suggested that above the c.m.c. the uranyl ion is bound by electrostatic interactions to the micellar surface [74], and, assuming a Langmuir-type adsorption isotherm, uranyl is suggested to bind more strongly than $d$-block cations such as $\mathrm{Cu}(\mathrm{II})$ or $\mathrm{Co}(\mathrm{II})$ [76].

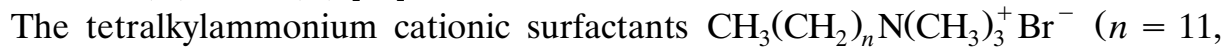
$15,17)$, are all found to be efficient quenchers of uranyl luminescence. However, the slopes of the Stern-Volmer plots at concentrations below the c.m.c. are identical to those observed using $\mathrm{KBr}$ or $\left(\mathrm{CH}_{3}\right)_{4} \mathrm{~N}^{+} \mathrm{Br}^{-}$, indicating that the quenching only comes from the bromide anion $[78,79]$. Using this idea the quenching can be used as a probe of the free bromide concentration in solution, and, hence, the counter-ion binding to the micelle. On this basis, a value of $\alpha=0.20$ can be calculated for the degree of bromide dissociation from CTAB micelles in aqueous solution, in agreement with values obtained by other techniques [80]. Similar uranyl fluorescence quenching experiments are being used to study the distribution of aliphatic alcohols between cationic micelles and aqueous domains [81].

Addition of uranyl chloride complexes to aqueous solutions of long chain alkylpyridinium (AP) chlorides above their c.m.c. has been found to lead to precipitation of luminescent compounds of general formula $(\mathrm{AP})_{2} \mathrm{UO}_{2} \mathrm{Cl}_{4}$ [82]. It is suggested that the micellar environment induces chloride complexation by the uranyl ion.

Detailed studies have been made on the quenching of uranyl luminescence in the presence of the non-ionic surfactant Triton X-100 $\left(\mathrm{C}_{8} \mathrm{H}_{17} \mathrm{C}_{6} \mathrm{H}_{4}\left(\mathrm{OCH}_{2} \mathrm{CH}_{2}\right)_{x} \mathrm{OH}\right.$, $9<x<10)[74,83,84]$. From both kinetic [83] and spectral [84] data it is suggested that whilst the majority of the uranyl ions are associated with the headgroup region, a substantial amount of them are able to penetrate into the micellar core. This is supported by ${ }^{13} \mathrm{C}$-NMR spectroscopy and by the quenching of azulene fluorescence by $\mathrm{UO}_{2}^{2+}$ [83].

\section{Water-in-oil (w / o) microemulsions and lyotropic liquid crystals}

The concentration and transport of uranium by extraction into non-polar solvents from aqueous solutions using water-in-oil microemulsions is an important process in the nuclear industry [85]. The most commonly used surfactant for these microemulsions is di(2-ethylhexyl)phosphoric acid (HDEHP), and a spectroscopic study as been reported of the complexation of $\mathrm{UO}_{2}^{2+}$ in the reversed micellar system water-HDEHP- $n$-heptane [86]. The uranyl luminescence spectrum is blue shifted compared with aqueous solutions. Furthermore, the emission is strongly quenched in the microemulsions and the luminescence lifetimes are multiexponential. It is suggested that some of the positively charged uranyl ions are tightly 
bound to phosphoryl headgroups, while others may be surrounded by their hydration sphere in the water pool of the reversed micelles [86].

Luminescence and absorption spectral measurements have also been made on uranyl ions in w/o microemulsions of water-benzylhexadecyldimethylammonium chloride (BHDC)-toluene [78] and water-AOT-cyclohexane [87]. In both cases, reduction in luminescence intensity, loss of vibronic structure and shifts in the emission and absorption bands are observed compared with aqueous solutions. With BHDC, it is suggested that both surfactant and $\mathrm{Cl}^{-}$interact with uranyl ions [78]. With the AOT system, the spectra are affected by the addition of acid [87], possibly due to different degrees of hydrolysis of the uranyl ions.

Studies have also been made on uranyl ion excited state in the lamellar $L_{\alpha}$ phase of AOT/water (50 wt.\%) lyotropic liquid crystals [88]. Studies using both luminescence and laser flash photolysis show a decrease in vibronic structure in the spectrum and a reduction in excited state lifetime compared with aqueous solution, possibly due to either different degrees of hydrolysis of uranyl ion or to its binding to the sulfonate headgroup of the surfactant. The quenching of uranyl luminescence by bromide and iodide ions was also studied in these systems, and dynamic quenching was observed [88]. However, the apparent second-order rate constants were lower than those observed in aqueous solutions [65]. This may be a consequence of the reduction in the dimensionality of the water domains in these liquid crystals.

\section{Vesicles and biological membranes}

Uranyl ions are known to interact strongly with phospholipid monolayers [89] and bilayers [90], and have been extensively used in studies of model lipid membranes because of their high affinity for the phosphate group [91,92]. However, we should note, in addition, that although uranyl acetate has been widely used as a stain for electron microscopy studies for surfactant vesicles and dispersions [93-95], there are indications that it can cause changes in phase behaviour [96]. Uranyl acetate has been used to photosensitize the killing of cells such as $E$. coli $K-12$ [97], with the reaction involving binding of uranyl ion to the cell membrane. Photophysical studies on these systems would, thus, be expected to be important methods to obtain information at the molecular level of the uranyl-lipid interactions.

Luminescence studies have been made on the behaviour of uranyl ions in synthetic vesicles $[79,81,87]$. Differences are observed in the behaviour with uranyl acetate in dimethyldidodecylammonium hydroxide vesicles when aqueous solutions are prepared by different methods. In particular, there are differences in the behaviour where the uranyl ion is both outside and inside the vesicle, and where it is localised just in the exterior aqueous domain. For the latter case, these results suggest association of uranyl ion at the exterior vesicle-water interface. Kinetic measurements show that this is, followed by transfer of the metal ion from the outside to the inside of the vesicles [81]. 


\section{Probing polymer systems}

Systems of uranyl ion with water-soluble polymers are increasingly being used for recovery and removal of this toxic cation from aqueous solutions [98,99]. They are also of potential use in photochemical graft copolymerisation [100,101]. In addition, the photo-induced cleavage of DNA by uranyl salts has been reported [102,103], and shows considerable potential for probing DNA conformations $[104,105]$ or for photofootprinting phosphate backbone contacts in protein-DNA complexes [106].

Steady-sate and dynamic studies on luminescence quenching of uranyl ions by poly(vinyl alcohol) in aqueous solutions show that there is a dynamic interaction, which leads to hydrogen atom abstraction from the polymer chain [100,107]. The dependence of the kinetics on the polymer concentration has been treated by a multi-equilibrium model [100], which has provided quantitative data on metal ion-polymer binding. Saturation occurs at high uranyl concentrations. Luminescence has also been used to study the interaction between uranyl ion and metallylsulfonate-vinylacetate copolymers in aqueous solutions [107]. Formation of non-fluorescent complexes is observed at low uranyl ion concentrations until all vacant sulfonate sites become occupied. At higher concentrations dynamic quenching by aggregates may be observed. The technique shows promise for the determination of metal ion binding sites in polyelectrolytes. Luminescence measurements have also been used to study the binding of uranyl ion to DNA [108] cellulose esters [108,109] and cellobiose [109].

Absorption spectra, luminescence spectra and excited state lifetimes have been studied with uranyl ion incorporated into polymeric membranes of the perfluorosulfonate Nafion [110,111] and the perfluorocarboxylate Flemion [110]. The excited state lifetimes show a dramatic dependence on water concentration, confirming that this plays an important role in excited state deactivation. Information on the nature of the adsorbed uranyl species in these systems can be obtained by comparison of luminescence spectra and X-ray diffraction data with those of various hydrolysed uranyl species, uranium oxides and uranates [110]. This will be discussed in more detail in Section 7. Energy transfer has been observed from uranyl ion to cobalt(II) [111] and europium(III) [110,111] ions in these membranes, and provides information on metal-metal bond distances and on metal ion clustering.

\section{Metal oxides and other colloidal particles}

A large number of examples have been reported of the use of luminescence to study the interaction of uranyl ion with metallic and non-metallic oxides, including alumina (III) [112-114], silica [115-119] and titanium dioxide [120], in addition to various zeolites [113,114,121-124] and clays [123,125-128]. Much of the interest in these systems derives from their applications in terms of long-term storage of nuclear wastes [128], in photocatalysis [121,129] and as catalysts for the efficient 
thermal degradation of pollutant molecules [130]. Luminescence measurements are particularly valuable for probing in these systems when used in conjunction with other techniques, such as Raman spectroscopy and X-ray diffraction [113], to determine the nature of bound uranyl species. For example, ion exchanged uranyl ion in the synthetic zeolite ZSM-20 is found to be present in the large cavities of the solid as dimers $[113,114]$. In contrast, studies of a uranyl ion containing zeolite ZSM-5 prepared by chemical synthesis show that uranyl is extensively hydrolysed, and may be bound to silanol groups [113,114].

Energy transfer from uranyl ion to europium(III) has been used in these systems to obtain information on the donor-acceptor distances, and also on the fractional dimensionality of the transfer process [124]. Quenching has been observed in the luminescence of uranyl ion incorporated in zeolites [121] and colloidal silica [115]. This provides a useful technique for studying the penetration of small organic and inorganic molecules in these solids.

Uranyl ion has potential as a photophysical probe for various other colloidal and microheterogeneous systems. For example, the luminescence has been used to compare the behaviour of synthetic and natural humic acids (HA) [131], and both excited state lifetime and spectral data give information of the metal ion-HA interactions. These studies can readily be extended to other naturally occurring colloidal systems. Luminescence has also been used to study the structures produced by incorporation of uranyl ion into lamellar phosphate [132,133], arsenate [133] and polyamine [134] solids. These can serve as valuable hosts for intercalation chemistry, and show considerable promise for applications in materials science.

\section{Conclusions and a caveat}

The results reviewed in this article show that uranyl ions are a valuable addition to the range of photophysical probes used for studying colloidal and surfactant systems, providing particularly useful data on dynamic processes in the microsecond time range. Both its spectral and kinetic features are useful. However, it is worth noting two important potential limitations. The $\mathrm{UO}_{2}\left(\mathrm{H}_{2} \mathrm{O}\right)_{5}^{2+}$ species is only stable in fairly acidic aqueous solutions [52]. Hydrolysed uranyl species are stable up to higher $\mathrm{pH}$ values, but for use in neutral or alkaline solutions it is necessary to complex uranyl with appropriate ligands. For example, uranyl fluoride complexes have been successfully employed for studying quenching behaviour in neutral solutions [135]. Here, uranyl ion is present as the species $\mathrm{UO}_{2} \mathrm{~F}_{4}\left(\mathrm{H}_{2} \mathrm{O}\right)^{2-}$ [136]. Various neutral and charged uranium(VI) complexes are available, which permit the use of this probe in a variety of aqueous solutions and non-aqueous solvents [137]. A second note of caution concerns possible structural changes which uranyl may induce in surfactant dispersions. These have been the subject of a review by Talmon [96]. Again, by judicious choice of conditions it is possible to minimise or eliminate these effects and use uranyl photophysics to obtain reliable structural and dynamic data. 


\section{Acknowledgements}

We are grateful to PRAXIS XXI (project 2/2.1/QUI/411/94) for financial support.

\section{References}

[1] Th. Förster, B. Selinger, Z. Naturförsch. A 19 (1964) 38.

[2] R.R. Hautala, N.E. Schore, N.J. Turro, J. Am. Chem. Soc. 95 (1973) 5508.

[3] H.J. Pownall, L.C. Smith, J. Am. Chem. Soc. 95 (1973) 3136.

[4] P.P. Infelta, M. Grätzel, J.K. Thomas, J. Phys. Chem. 78 (1974) 190.

[5] M. Tachiya, Chem. Phys. Lett. 33 (1975) 289.

[6] M.R. Eftink, C.A. Ghiron, J. Phys. Chem. 80 (1976) 486.

[7] K. Kalyanasundaram, J.K. Thomas, J. Am. Chem. Soc. 99 (1977) 2038.

[8] N.J. Turro, A.K. Yekta, J. Am. Chem. Soc. 100 (1978) 5951.

[9] M. Almgren, J.-E. Löfroth, J. Colloid Interface Sci. 81 (1981) 486.

[10] K. Kalyanasubndaram, Chem. Soc. Rev. 7 (1978) 453.

[11] J.K. Thomas, Chem. Rev. 80 (1980) 283.

[12] M.A. Winnik (Ed.), Photochemical and Photophysical Tools in Polymer Science, D. Reidel, Dordrecht, 1986.

[13] R. Zana (Ed.), Surfactants in Solution: New Methods of Investigation, Marcel Dekker, New York, 1986.

[14] K. Kalyanasundaram, Photochemistry in Microheterogeneous Systems, Academic Press, Orlando, 1986.

[15] J.K. Thomas, J. Phys. Chem. 91 (1987) 267.

[16] F. Grieser, C.J. Drummond, J. Phys. Chem. 92 (1988) 5580.

[17] M. Almgren, in: M. Grätzel, K. Kalyanasundaram (Eds.), Kinetics and Catalysis in Microheterogeneous Systems, chap. 4, Marcel Dekker, New York, 1991.

[18] M. Almgren, Adv. Colloid Interface Sci. 41 (1992) 9.

[19] M.H. Gehlen, F.C. De Schryver, Chem. Rev. 93 (1993) 199.

[20] F.A. Winnik, S.T.A. Regismond, Colloids Surf. A 118 (1996) 1.

[21] M. Almgren, J. Alsins, Isr. J. Chem. 31 (1991) 159.

[22] B. Medhage, M. Almgren, J. Fluoresc. 2 (1992) 7.

[23] B. Medhage, M. Almgren, J. Alsins, J. Phys. Chem. 97 (1993) 7753.

[24] A.J. Frank, M. Grätzel, A. Henglein, E. Janata, Ber. Bunsenges Phys. Chem. 80 (1976) 294.

[25] K. Kalyanasundaram, F. Grieser, J.K. Thomas, Chem. Phys. Lett. 51 (1977) 501.

[26] M. Almgren, F. Grieser, J.K. Thomas, J. Am. Chem. Soc. 101 (1979) 2021.

[27] E. Geladi, F.C. De Schryver, J. Am. Chem. Soc. 106 (1984) 5871.

[28] M. Charntoff, T.D.Z. Atvas, Macromolecules 32 (1999) 6093.

[29] J. Lang, A. Jada, A. Malliaris, J. Phys. Chem. 92 (1988) 1946.

[30] R. Jóhannsson, M. Almgren, J. Alsins, J. Phys. Chem. 35 (1991) 3819.

[31] W. De W. Horrocks Jr., M. Albin, Prog. Inorg. Chem. 31 (1984) 1.

[32] W.D.eW. Horrocks Jr, D.R. Sudnick, J. Am. Chem. Soc. 101 (1979) 334.

[33] S.T. Frey, W.D.eW. Horrocks Jr, Inorg. Chim. Acta 229 (1995) 383.

[34] H.N. Halladay, M. Petersheim, Biochemistry 27 (1988) 2120.

[35] S.M. Yeh, C.F. Meares, Experientia 35 (1979) 715.

[36] W. Dong, C.D. Flint, J. Chem. Soc. Farday Trans. 88 (1992) 2661.

[37] G.D. Correll, R.N. Chester III, F. Nome, J.H. Fendler, J. Am. Chem. Soc. 100 (1978) 1254.

[38] J.R. Darwent, W. Dong, C.D. Flint, J. Chem. Soc. Faraday Trans. 89 (1993) 873. 
[39] R.J. Hill, T.J. Kemp, D.M. Allen, A. Cox, J. Chem. Soc. Faraday Trans 170 (1974) 847.

[40] G.I. Sergeeva, A.K. Chibisov, L.V. Levshin, A.V. Karyakin, J. Photochem. 5 (1976) 253.

[41] A. Bakac, H.D. Burrows, Appl. Spectrosc. 51 (1997) 1916.

[42] M. Åberg, D. Ferri, J. Glaser, I. Grenthe, Inorg. Chem. 22 (1983) 3986.

[43] M.da G. Miguel, S.J. Formosinho, A.C. Cardoso, H.D. Burrows, J. Chem. Soc Faraday Trans. 1 80 (1984) 1735.

[44] M.E.D.G. Azenha, H.D. Burrows, S.J. Formosinho, M.L.P. Leitão, M. da G. Miguel, J. Chem. Soc. Dalton Trans, (1988) 2893.

[45] P.G. Allen, J.J. Bucher, D.-K. Shuh, N.M. Edelstein, T. Reich, Inorg. Chem. 36 (1997) 4676.

[46] A.P. Daramanyan, I.V. Khudyakov, Photochem. Photobiol. 52 (1990) 293.

[47] J.T. Bell, R.E. Biggers, J. Mol. Spectrosc. 18 (1965) 247.

[48] J.G. Alpress, A.N. Hambly, Aust. J. Chem. 12 (1959) 569.

[49] M.E.D.G. Azenha, H.D. Burrows, S.J. Formosinho, M.da G. Miguel, A.P. Daramanyan, I.V. Khudyakov, J. Lumin. $48 / 49$ (1991) 522.

[50] C. Gorller-Walrand, S. De Jaegere, Spectrochim. Acta A 28A (1972) 257.

[51] F.A. Cotton, G. Wilkinson, Advanced Inorganic Chemistry, 5th ed, Wiley, New York, 1988, p. 1009.

[52] R.N. Sylva, M.R. Davidson, J. Chem. Soc., Dalton Trans., (1979) 465.

[53] C. Moulin, I. Laszak, V. Moulin, C. Tondre, Appl. Spectroc. 52 (1998) 528.

[54] C.D. Flint, P.A. Tanner, J. Chem. Soc., Faraday Trans. 280 (1984) 219.

[55] S.J. Formosinho, M.da G. Miguel, J. Chem. Soc., Faraday Trans. 180 (1984) 1745.

[56] M. Lopez, D.J.S. Birch, Chem. Phys. Lett. 268 (1997) 125.

[57] H.D. Burrows, S.J. Formosinho, M. da, G. Miguel, F. Pinto Coelho, Mem. Acad. Ciências Lisboa 19 (1976) 185.

[58] V. Balzani, F. Bolletta, M.T. Gandolfi, M. Maestri, Top. Curr. Chem. 75 (1978) 1.

[59] C.K. Jorgensen, R. Reisfield, Struct. Bonding 50 (1982) 121.

[60] H.D. Burrows, T.J. Kemp, Chem. Soc. Rev. 3 (1974) 139.

[61] H.D. Burrows, S.J. Formosinho, F. Pinto Coelho, M.da G. Miguel, M.E.D.G. Azenha, Mem. Acad. Ciências Lisboa 30 (1989) 33.

[62] M.E.D.G. Azenha, H.D. Burrows, S.J. Formosinho, M.da G. Miguel, J. Chem. Soc. Faraday Trans.1 85 (1989) 2625.

[63] H.D. Burrows, S.J. Formosinho, M. da, G. Miguel, F. Pinto Coelho, J. Chem. Soc., Faraday Trans. 172 (1976) 163.

[64] H.D. Burrows, A.C. Cardoso, S.J. Formosinho, M. da, G. Miguel, J. Chem. Soc., Faraday Trans. 1 81 (1985) 49.

[65] H.D. Burrows, Inorg. Chem. 29 (1990) 139.

[66] C.P. Baird, T.J. Kemp, Prog. Reaction Kinetics 22 (1997) 87.

[67] H. Gusten, Gmelin Handbook of Inorganic Chemistry, Uranium Supplement, A6, SpringerVerlag, Berlin, 1983, p. 80.

[68] R.G. Denning, Struct. Bonding 79 (1992) 215.

[69] E. Pramauro, A.B. Prevot, E. Pelizzetti, R. Marchelli, A. Dossena, A. Biancardi, Anal. Chim. Acta 264 (1992) 303.

[70] A.L. Buchachenko, I.V. Khudyakov, Acc. Chem. Res. 24 (1991) 177.

[71] I.V. Khudyakov, A.L. Buchachenko, Mendeleev Comm., (1993) 135.

[72] S.J. Formosinho, L.-M. Martinho do Rosário, Rev. Port. Quím. 20 (1978) 88.

[73] D. Meisel, W. Mulac, J.C. Sullivan, Inorg. Chem. 20 (1981) 4247.

[74] C. Moulin, P. Reiller, C. Beaucaire, D. Lemordant, J. Colloid Interface Sci. 157 (1993) 411.

[75] C. Moulin, P. Reiller, C. Beaucaire, D. Lemordant, Appl. Spectrosc. 47 (1993) 2172.

[76] P. Reiller, D. Lemordant, C. Moulin, C. Beaucaire, J. Colloid Interface Sci. 163 (1994) 81.

[77] P. Reiller, D. Lemordant, A. Hafiane, C. Moulin, C. Beaucaire, J. Colloid Interface Sci. 177 (1996) 519.

[78] H.D. Burrows, M. da G. Miguel, S.J. Formosinho, Abstracts 6th International Symposium on Surfactants in Solution, New Delhi, 1986.

[79] H.D. Burrows, M. da G. Miguel, M.F. Lopes da Silva, M.A.R. Escaroupa, unpublished results. 
[80] M.N. Jones, J. Piercy, J. Chem. Soc., Faraday Trans. 168 (1972) 1839.

[81] M. da G. Miguel, A.P. Varela, H.D. Burrows, manuscript in preparation.

[82] R.A. Singh, A.V. Sapre, S.R. Dharwadkar, K.V.S. Rama Rao, Thermochim. Acta 131 (1988) 79.

[83] S.J. Formosinho, M.da G. Miguel, J. Chem. Soc. Faraday Trans. 181 (1985) 1891.

[84] S.K. Das, B.N. Ganguly, J. Colloid Interface Sci. 180 (1996) 377.

[85] C.A. Blake, Oak Ridge National Laboratory Report, ORNL-2172.

[86] B.N. Ganguly, J. Photochem. Photobiol. A 51 (1990) 401.

[87] H.D. Burrows, M. da G. Miguel, L.A. Girão da Cruz, to be published.

[88] H.D. Burrows, A.P.G.V. Souto, unpublished observations.

[89] M.M. Standish, B.A. Pethica, Trans. Faraday Soc. 64 (1968) 1113.

[90] H. Hauser, C.C. Hinckley, J. Krebs, B.A. Levine, M.C. Phillips, R.J.P. Williams, Biochim. Biophys. Acta 468 (1977) 364.

[91] H. Ginsburg, J.M. Wolosin, Chem. Phys. Lipids 23 (1979) 125.

[92] L. Pasquale, A. Winiski, C. Oliva, G. Vaio, S. McLaughlin, J. Gen. Physiol. 88 (1986) 697.

[93] T. Kunitake, Y. Okahata, J. Am. Chem. Soc. 102 (1978) 549.

[94] A.H. Falls, H.T. Davis, L.E. Schryven, Y. Talmon, Biochim. Biophys. Acta 693 (1982) 364.

[95] S. Lacouturière, S. Piekarski, J. Chim. Phys. 84 (1987) 941.

[96] Y. Talmon, J.Colloid Interface Sci. 93 (1983) 366.

[97] W.C. Neely, S.P. Ellis, R.M. Cody, Photochem. Photobiol. 13 (1971) 503.

[98] Proceedings of the International Meeting of Recovery of Uranium from Seawater, Atomic Society of Japan, Tokyo (1983).

[99] A. Nakajima, T. Sakaguchi, J. Chem. Technol. Biotechnol. 36 (1986) 281.

[100] H.D. Burrows, S.J. Formosinho, P.M. Saraiva, J. Photochem. Photobiol. A 63 (1992) 67.

[101] M. da G. Miguel, H.D. Burrows, manuscript in preparation.

[102] P.E. Nielsen, C. Hiort, S.H. Sonnichsen, O. Buchardt, O. Dahl, B. Nordèn, J. Am. Chem. Soc. 114 (1992) 4967.

[103] A.R. Hill, L.E. Orgel, Bioconjugate Chem. 2 (1991) 431.

[104] P.E. Nielsen, N.E. Mollegaard, C. Jeppesen, Anti Cancer Drug Des. 5 (1990) 105.

[105] P.E. Nielsen, N.E. Mollegaard, C. Jeppesen, Nucl. Acid Res. 18 (1990) 3847.

[106] P.E. Nielsen, C. Jeppesen, O. Buchardt, FEBS Lett. 235 (1988) 122.

[107] M.G. Neumann, M.J. Tiera, H.D. Burrows et al., Quím. Nova 14 (1991) 257.

[108] S.M. Fonseca, H.D. Burrows, M. da G. Miguel, to be published.

[109] S.M. Fonseca, M.Sc. Thesis, University of Coimbra, 1998.

[110] J.M. Kelly, H.M. Meunier, D.E. McCormack, A. Michas, M. Pineri, Polymer 31 (1991) 387.

[111] M. Lopez, D.J.S. Birch, J. Lumin. 71 (1997) 221.

[112] H.D. Burrows, S.J. Formosinho, M.A. Pedrosa, J. Mol. Struct. 143 (1986) 223.

[113] M.E.D.G. Azenha, Ph.D. Thesis, University of Coimbra (1998).

[114] M.E.D.G. Azenha, M. da G. Miguel, S.J. Formosinho, H.D. Burrows, J. Mol. Struct., submitted for publication.

[115] J. Wheeler, J.K. Thomas, J. Phys. Chem. 88 (1984) 750.

[116] S. Dai, Y.S. Shin, L.M. Toth, C.E. Barnes, J. Phys. Chem. B 101 (1997) 5521.

[117] S. Dai, Y.S. Shin, C.E. Barnes, L.M. Toth, Chem. Mater. 9 (1997) 2521.

[118] Yu.D. Glinka, M. Jaroniec, V.M. Rozenbaum, J. Colloid Interface Sci. 194 (1997) 455.

[119] J.P. Young, R.W. Shaw, O.F. Wrebb, Inorg. Chem. 38 (1999) 5192.

[120] R. Amadelli, A. Maldotti, S. Sostero, V. Carraitti, J. Chem. Soc. Faraday Trans. 87 (1991) 3267.

[121] S.L. Suib, A. Kostapapas, D. Psaras, J. Am. Chem. Soc. 106 (1984) 1614.

[122] S.L. Suib, K.A. Carrado, Inorg. Chem. 24 (1985) 200.

[123] S.L. Suib, J.F. Tanguay, M.L. Ocelli, J. Am. Chem. Soc. 108 (1986) 6972.

[124] C.-I. Yang, M.A. El-Sayed, S.L. Suib, J. Phys. Chem. 91 (1987) 4440.

[125] S.L. Suib, K.A. Carrado, Inorg. Chem. 24 (1985) 863.

[126] D.E. Morris, C.J. Chisholm-Brause, M.E. Barr, S.D. Conradson, P.G. Eller, Geochim. Cosmochim. Acta 58 (1994) 3613.

[127] C. Chisholm-Brause, S.D. Conradson, C.T. Buscher, P.G. Eller, D.E. Morris, Geochim. Cosmochim. Acta 58 (1994) 3625. 
[128] D.E. Morris, P.G. Allen, J.M. Berg et al., Environ. Sci. Technol. 30 (1996) 2322.

[129] S. Dai, D.-H.- Metcalfe, G.D. Del Curl, L.M. Toth, Inorg. Chem. 35 (1996) 7786.

[130] S.D. Pollington, A.F. Lee, T.L. Overton, R.J. Sears, P.B. Wells, S.F. Hawley, I.D. Hudson, D.F. Lee, V. Ruddock, Chem. Commun. (1999) 725.

[131] S. Pompe, M. Bubner, M.A. Denecke et al., Radiochim. Acta 74 (1996) 135.

[132] M.M. Olken, R.N. Biagioni, A.B. Ellis, Inorg. Chem. 22 (1983) 4128.

[133] P.K. Dorhout, G.L. Rosenthal, A.B. Ellis, Inorg. Chem. 27 (1988) 1159.

[134] D. Grohol, E.L. Blinn, Inorg. Chem. 36 (1997) 3422.

[135] R. Billing, G.V. Zakharova, L.S. Atabekyan, H. Henning, J. Photochem. Photobiol. A 59 (1991) 163.

[136] M.E.D.G. Azenha, H.D. Burrows, S.J. Formosinho, M.L.P. Leitão, M. da G. Miguel, manuscript in preparation.

[137] I. Grenthe, J. Fuger, R.J.M. Konings, A.B. Muller, C. Nguyen-Trung, H. Wanner, Chemical thermodynamics of uranium, North-Holland, Amsterdam, 1992. 